\title{
Kolorektal Kanser ve D Vitamini
}

\author{
Colorectal Cancer and Vitamin D
}

\author{
Burcu Merve AKSU ${ }^{1}$ (D), Esra Tansu SARIYER ${ }^{2}$
}

ÖZ

Kolorektal kanser dünyada üçüncü sırada yaygın görülen kanser türüdür. Kolorektal kanser risk faktörlerinden biri düşük D vitamini düzeyidir. D vitamini eksikliği dünyada artış gösteren bir sağlık sorunudur. D vitamini aktif formu kalsitriol olarak bilinen 1,25-Dihidroksikolekalsiferoldur. Bu form bazı biyolojik süreçler ve immün sistem düzenlenmesinde görev alır. D vitamini kolon, meme, prostat gibi pek çok kanser türü ile ilişkilidir. Tedavi sürecinde de önemli etkileri olan $\mathrm{D}$ vitaminin cerrahi müdahale veya kemoterapi tedavisi sonrası plazma seviyesinin yüksek olması daha iyi sağ kalım ile ilişkili bulunmuştur.

Anahtar Kelimeler: Beslenme, D vitamini, D vitamini reseptörü, Kanser, Kolorektal kanser.

\begin{abstract}
Colorectal cancer is the third most common type of cancer in world. One of the risk factors for colorectal cancer is low vitamin D level. Vitamin D deficiency is an increasing health problem in the world. The active form of vitamin $\mathrm{D}$ is 1,25 -dihydroxy vitamin $\mathrm{D}$, known as calcitriol. This form is involved in some biological processes and immune system regulation. Vitamin D is associated with many types of cancer such as colon, breast, prostate. The high levels of vitamin $\mathrm{D}$, which has important effects in the treatment process, has been found to be associated with better survival after surgery or chemotherapy treatment.
\end{abstract}

Keywords: Nutrition, Vitamin D, Vitamin D receptor, Cancer, Colorectal cancer

Burcu Merve AKSU

Demiroğlu Bilim Üniversitesi, Sağlık Bilimleri Fakültesi, Beslenme ve Diyetetik Bölümü

Esra Tansu SARIYER $(\bowtie)$

Üsküdar Üniversitesi, Sağllk Bilimleri Fakültesi, Beslenme ve Diyetetik Bölümü

e-mail:esratansu.sariyer@uskudar.edu.tr

\section{GíRiş}

Endüstrileşmiş ülkelerde daha yaygın tanı alan kolorektal kanser görülme sıklığı açısından üçüncü sırada, mortalite açısından ikinci sırada bulunmaktadır $(1,2)$. Güneş ışığını daha az alan ülkelerde ise kolorektal kanser prevalans1 yükselmektedir (3). Kanser hastalarında D vitamini düzeylerinde düşüklük veya yetersizlik görülmektedir (4). Güneş ışığı etkisiyle vücutta sentezlenen aktif $\mathrm{D}$ vitamini ve D vitamini reseptörü (VDR) kanser prognoz ve mortalitesi ile ilişkilidir (3). Bu derlemenin amacı kolorektal kanser ile D vitamini arasındaki ilişkinin incelenmesidir.

\section{Kolorektal Kanser}

Gelişmiş ülkelerde daha sık görülen kolorektal kanser 2012 y1lı verilerine göre görülme sıklığ 1 açısından üçüncü sırada, mortalite açısından dördüncü sırada bulunmaktadır $(5,6,7)$. Uluslararası Kanser Araştırma Kurumu'nun Global Kanser İzlemi (GLOBOCAN) 2018 y1lı verilerine göre ise; her iki cinsiyette görülme oranı değişmezken, mortalite açısından incelendiğinde akciğer kanserinden sonra ikinci sirada bulunmaktadır (2). Kolorektal kanser 2012 yılı verilerine göre yaklaşık olarak 746000 erkek ve 614000 kadını etkilemiştir (9). Ülkemizde Sağlık Bakanlığı 2014 y1lı Türkiye Kanser İstatistiklerine göre meme kanseri ve tiroid kanserinden sonra üçüncü sırada bulunmaktadır (8).

Kolorektal kanser için risk faktörleri inflamatuar bağırsak hastalığı, kırmızı et, sebze, meyve tüketim durumları, sigara kullanımı, beden kütle indeksi, ırk, alkol tüketimi, fiziksel aktivite, B grubu vitaminleri alımı (B6, B9, B12), serum kalsiyum ve D vitamini düzeyi ile ilişkilidir (1). Hastalığın görülme sıklığı ile bireylerin diyet tercihleri arasındaki ilişki epidemiyolojik çalışmalar ile değerlendirilmiştir. Sonucunda ise akdeniz diyeti gibi bitkisel besin temelli diyetlere karşın, 
aşırı hayvansal kaynaklı protein içeren diyetleri tüketen bireylerde hastalığın görülme sıklığının daha az olduğu bulunmuştur (6). Genetik yatkınlık ile birlikte beslenme ve fiziksel aktivite gibi çevresel faktörlerin de kolorektal kanser gelişimine etki ettiği bilinmektedir. Yaşam tarzı faktörleri arasında yüksek beden kütle indeksi, obezite ve fiziksel inaktivite bulunmaktadır. Beslenmeye bağlı olarak obezite, artan vücut yağı ve abdominal yağlanma kolon kanseri riskini artırmakla birlikte obezitenin sağkalım üzerine olumsuz etki oluşturduğunu gösteren epidemiyolojik kanitlar vardır (5).

Abdominal adipoz dokusu endokrin etkileri olan bir organ gibi işlev göstermektedir. Abdominal yağlanmadaki artış insülin direnci ve insülin, insülin benzeri büyüme faktörü (IGF-1), leptin, adiponektin gibi hormon ve sitokinlerin düzeylerinde değişime neden olmaktadır. Obezite tümorigenez ve proliferasyonun artması, tümör hücrelerinde apoptozun azalması ile ilişkilidir. Ek olarak yağ oranı yüksek bir beslenme modeli tümör hücrelerinde proliferasyon yeteneği ve akciğer metastazında artışına neden olmaktadir (5).

Yüksek kırmızı et ve işlenmiş et ürünleri tüketiminin kolorektal kanser riskini artırdığı epidemiyolojik çalışmalar ile gösterilmiştir. $\mathrm{Bu}$ ilişkide üç etki mekanizmasından bahsedilmektedir. İlk mekanizma işlenmiş et ürünlerinin içerdiği nitrit veya nitratın gastrointestinal sistemde kanserojen etki gösteren N-nitrozo bileşiklerine dönüşümüdür. İkinci mekanizma yanlış pişirme yöntemleri sonucu heterosiklik aminlerin oluşumudur. Üçüncü mekanizma ise hayvansal kaynaklı ürünlerde bulunan hem demirin epitel hücreler üzerindeki sitotoksik ve genotoksik etkileridir (10).

Lif alımı ile kolorektal kanser arasında ise ters bir ilişki olduğu bilinmektedir. Çin'de yapılan çalışmada ise bu bilgiye ek olarak sebze ve soya bazlı besinlerin tüketiminin kolorektal kanser riskini azaltıcı etkileri olduğu da gösterilmiştir (11).

Bağırsak mikrobiyotası diyet alışkanlıkları, kültürel farklılıklar, çevre, fiziksel ve psikolojik stres, yaş, radyasyon, kimyasallar, fizyolojik durum ve ilaç kullanımı gibi durumlara bağlı olarak değişmektedir $(6$, 7). Prebiyotikler, memeli hayvanların enzimleri tarafindan sindirilmeyen ve kolona ulaşarak fermente olup konakçı sağlığ1 için gastrointestinal mikrobiyotada bulunan yararlı bakterilerin büyümesini destekleyici fonksiyonel bileşenlerdir. Prebiyotikler, faydalı bakterilerin, özellikle laktobasiller ve bifidobakterilerin yanı sıra özellikle bütirat gibi kısa zincirli yağ asitleri ve sakkarolitik metabolitlerinin seçici olarak uyarılmasını sağlamaktadır. Oligofruktoz, laktuloz, izomaltooligosakkarit, ksilooligosakkaritler, inülin tipi fruktanlar, galaktooligosakkarit ve arabinoksilanoligosakkaritler gibi farklı prebiyotik türleri bulunmaktadır (12). Sindirilemeyen karbonhidratlar grubunda bulunan fruktanlardan olan inülin suda çözülebilir bir polisakkarittir. İnülin sebze ve meyvelerde yüksek miktarlarda bulunur. İnülin üst gastrointestinal sistemde, sindirimden kaçarak kolonda fermente olarak prebiyotik özellik göstermektedir. İnülin mikrofloranın yararlı bileşeni olarak kabul edilen "Bifidobakteria" gibi mikroorganizmaların çoğalmasını stimüle etmektedir. Bifidobakterilerin patojenlere karşı koruyucu olmanın yanı sıra, B vitamini, antioksidan bileşikler ve konjuge linoleik asit üretimi ile immün sistemi indükleyici özellikleri olduğu kabul edilmektedir. Bifidobakteriaların artışı ile bütirat oluşumunda da artış gözlenmektedir (13). Kısa zincirli yağ asitleri, beta-katenin, p53, p21, Bax ve kaspaz-3 genleri gibi çok sayıda hücre proliferasyonu ve apoptoz regülatörüne etki etmektedir (1). Bütirat kolonositlerin farklılaşması, büyümesi, apoptozisin desteklenmesi ve metastazın azalmasında etki göstermektedir (13, 14). Başka bir etkisi ise; kalsiyumun sindirim ve emilimini artırıcı etki göstererek, kemiklerde kalsiyum birikimine teşvik etmesidir. Bu sayede kanser ve osteoporoz gibi hastalıklara karşı korumada ve tedavisinde pozitif etki göstermektedir (13).

Yaş kolorektal kanser patogenezinde etkili olan başka bir faktördür. Yaş artışı ile birlikte vücutta toplam bakteri sayısı azalırken mikrobiyota bileşiminde Firmicutes sayısında azalma, Bacteroidetes oranında artış ile değişim gözlenmektedir. Bu durum ile birlikte koruyucu bakterilerde azalma görülür, karsinogenezi kolaylaştırıcı ortam oluşur. Hayvan çalışmalarında Bifidobacterium ve Lactobacillus, özellikle B. lactis, B. longum, L. acidophilus, L. casei ve L.rhamnosus'un mikrobiyal enzimleri etkisiz hale getirerek antikarsinojenik etkiler gösterdikleri öne sürülmektedir (6).

Metabolik sendrom kanser gelişimi ve kanser mortalitesi ile ilişkilidir. Bu ilişkinin açıklanmasında insülin direnci ve IGF-1'in önemli bir rol oynadı̆̆ı, özellikle visseral adipositlerden salgılanan adipokinlerin, serbest yă asitlerinin ve aromataz aktivitesinin bu sürece katkıda bulunduğu ileri sürülmektedir (15).

Polifenoller çay, kahve, şarap, meyve, sebze, tam tahıl ürünleri gibi bitkisel kaynaklı besinlerin doğal olarak içerdikleri biyoaktif bileşenlerdir. Polifenoller kolorektal kanserde kemopreventif rol oynayabilmektedir. 


\section{Vitamini}

Polifenollerin; kolorektal kansere karşı nüklear faktör (NF)-k $\beta$ 'nin modülasyonuna etki ederek kolorektal kansere karş1 koruyucu özellik gösterdiği kabul edilmektedir (7). Polifenollerin eikosanoid sentez modifikasyonu, DNA sentezinin düzenlenmesi, COX-2, NF-кB, AP-1, TNF, IL-6 inflamatuar yolakların aşağı modülasyonu ve $\beta$-glukuronidaz, $\beta$-glukosidaz, $\beta$-galaktosidaz gibi luminal detoksifikasyon enzimlerinin indüksiyonunu sağladıkları çalışmalar ile gösterilmiştir (16). Total polifenol alımı ile her iki cinsiyette kolorektal kanser arasında ilişkili bulunamazken; kahve tüketimi ile birlikte fenolik asit alımının erkeklerde kolon kanseri ile ters ilişkili ve kadınlarda ise rektal kanser ile pozitif ilişkili olduğu saptanmıştır. Günde 5 fincandan fazla, yani yüksek doz kahve alımının, kolon kanseri riskini azalttığı bildirilmiştir (7).

Diyet, kanserden korunmada anahtar rol oynamaktadır. Kolorektal kanser vakalarının yarısından fazlasının beslenme ve yaşam tarzı değişiklikleri ile önlenebilir olduğu düşünülmektedir. Beslenme ve kolorektal kanser arasındaki ilişkide; N-nitroso bileşikleri, anti-inflamatuar etki, DNA sentezine ve metilasyonuna katkı sağlama, kanser hücresi çoğalmasının önlenmesi, serbest yağ asitleri ve safra asitlerine bağlanma, antikanserojenik özellikte olan kısa zincirli yağ asitleri üretimi, insülin düzeyini düşürme ve yağlanmaya bağlı metabolik aktivite dahil olmak üzere bir dizi mekanizma mevcuttur (17).

Klinik veriler birçok malign kanserin hiperkalsemi ile ilişkili olduğunu düşündürmektedir. Hiperkalsemi, mide ve kolon tümörlerinin proliferasyonunu ve metastazını kolaylaştırabilir, bu durum da terminal dönem hastalığının ayırt edici özelliği olarak kabul edilir. Bununla birlikte, diyet kalsiyum veya $\mathrm{D}$ vitamini takviyesinin birçok kanser türü riskini azaltabileceği de bildirilmiştir. Özellikle, bağırsaklar kalsiyum $\left(\mathrm{Ca}^{+2}\right)$ geçirgen iyon kanalları yoluyla önemli miktarda kalsiyum emilimi yapabilmektedir. Bununla ilişkili olarak kolorektal kanserli hastalarda hiperkalsemi yaygındır. Hücre içi $\mathrm{Ca}^{+2}$ sinyal yolağında hafif bir artış bile kolorektal kanserin başlamasını ve ilerlemesini kolaylaştırabilmektedir. Bunun aksine, devaml $\mathrm{Ca}^{+2}$ akışı ve aşırı $\mathrm{Ca}^{+2}$ yüklenmesi ile de tümör hücresi ölümüne neden olabileceği görülmektedir. Bu bağlamda, $\mathrm{Ca}^{+2}$ sinyal yolağı bu şekilde ikili işlev göstermektedir (18).
D vitamini kolesterolden sentezlenen steroid yapıda bir hormondur (19). Yağda çözünen bir vitamin olan D vitamini, cildin güneşten gelen ultraviyole 1şı̆̆ına maruz kalması ile birlikte çoğunlukla endojen olarak sentezlenir. D vitamininin; yağlı tuzlu su balıkları, karaciğer ve yumurta sarısı gibi hayvansal kaynaklı besinlerde bulunan provitamin formu kolekalsiferoldür (D3). Bitkisel kaynaklı besinlerde bulunan provitamin formu ise ergokalsiferoldür (D2) (1). Deride 7-dehidrokolesterolden sentezlenen veya diyet ile vücuda alınan $\mathrm{D}$ vitamini, karaciğerde 25-hidroksilaz enzimleri aracıllğı hidroksillenerek, 25-hidroksivitamin D'ye dönüştürülür. Sonrasında bu formundan, böbreklerde bulunan 1a-hidroksilaz enzimi tarafından, 1,25-dihidroksivitamin D oluşturulur ve hücrede D vitamini reseptörü ile etkileşime girer (20). D vitaminin fizyolojik olarak aktif formu 1,25-dihidroksivitamin D3 (kalsitriol)'tür (1).

Türkiye Beslenme Rehberi (TÜBER)'e göre D vitamini gereksinimi $15 \mu \mathrm{g} / \mathrm{gün}$ 'dür. Türkiye genelinde ve tüm yaş gruplarında tüketim açığı en yüksek olan besin öğesi D vitaminidir (21). Dünya Sağlık Örgütü D vitamini düzeylerini, $20 \mathrm{ng} / \mathrm{mL}(50 \mathrm{nmol} / \mathrm{L})$ altındaki $\mathrm{D}$ vitamini düzeylerini yetersizlik ve $10 \mathrm{ng} / \mathrm{mL}(25 \mathrm{nmol} / \mathrm{L})$ altındaki D vitamini düzeylerini de eksiklik olarak tanımlamaktadır. Bununla birlikte; Pediatrik Endokrin Derneği, Endokrin Derneği ve Amerika Tıp Enstitüsü kuruluşları ise $10 \mathrm{ng} / \mathrm{mL}$ ( $25 \mathrm{nmol} / \mathrm{L})$ ile $30 \mathrm{ng} / \mathrm{mL}$ ( $75 \mathrm{nmol} / \mathrm{L})$ arasında değişmekte olan farklı D vitamini yetersizlik ve eksiklik sinır değerlerini kabul etmektedir (22). D vitamini vücutta yeterli olmadığında; kas zayıflığı, kalp damar hastalıkları, insülin metabolizmasında ve bağışıklık sisteminde bozulmalar gibi sağlı sorunlarının ortaya çıktığı bilinmektedir. D vitaminin antikanserojen etkileri ile tümör hücre büyümesini baskılayıcı etkileri üzerinde duran çalışmalar da mevcuttur. Antikanserojen etkisi antiproliferatif, proapoptoz, antianjiyojenez, antiinflamatuar etkilerinden ileri gelmektedir (4).

\section{Vitamini ve Kolorektal Kanser}

Güneş 1şı̆̆ının az olduğu ülkelerde mesane kanseri, meme kanseri, kolon-rektum kanseri, akciğer kanseri, özofagus kanseri, oral kanser, yumurtalık kanseri, pankreas kanseri, cilt kanseri ve mide kanseri ölüm oranının arttığ tespit edilmiştir. Güneş ışığının düşük olduğu ülkelerde kanser mortalite oranı yüksektir. Bu ilişkinin açıklanması 
için daha çok transkripsiyonel ve genomik verilere ihtiyaç vardır (3).

D vitamini kalsiyum homeostazı, doğal ve adaptif bağışıklık gibi çeşitli fizyolojik süreçlerin etkili bir düzenleyicisidir. Moleküler düzeyde $\mathrm{D}$ vitamininin etkilerine VDR aracılık eder (23). D vitamini kanser hastalığ 1 üzerindeki etkilerini ilişkili bazı yolaklar aracılığıyla göstermektedir (24). VDR, kolorektal kanserde daha iyi prognoz ile ilişkilidir (3). VDR bir transkripsiyon faktörü ve nükleer reseptör süper ailesinin bir üyesidir. Bağırsakta VDR eksikliği, anormal Paneth hücrelerine ve bozulmuş otofaji fonksiyonuna yol açar. Buna ek olarak, VDR eksikliğinin daha fazla apoptotik hücre indüklediği bildirilmiştir. Proapoptotik protein B hücresi lenfoma 2 (BCL-2) ile ilişkili $\mathrm{X}$ proteini (Bax) arttırılırken, otofaji ile ilişkili 16 benzeri 1 (ATG16L1) ve Beclin-1 seviyeleri bağırsakta azalmaktadır. Bax'ın neden olduğu apoptoz, Beclin-1 seviyelerini azaltarak otofajiyi azaltıcı etki göstermektedir (25). VDR, endoplazmik retikulum stres proteini-57 ile birlikte güneş ışığına bağlı meydana gelen DNA hasarını önleyici etki göstermektedir (24). Epidemiyolojik ve deneysel çalışmalar, VDR ve ligandlarının kanser, otoimmün hastalıklar ve enfeksiyonların yanı sira kemik ve mineral bozukluklarının önlenmesi ve olası tedavisi için umut verici hedefler olduğunu ortaya koymaktadır (23).

D vitamini hedef aldığı hücreye ulaştığında VDR'nin aktif hale geçmesi ile etkinlik gösterir. Yeterli güneş 1şı̆̆ 1 alamayan bireylerde görülen $\mathrm{D}$ vitamini düzeyi düşüklüğü VDR'nin aktif halde olamaması veya bozukluğuna işaret edebilmektedir. $\mathrm{Bu}$ durumda $\mathrm{D}$ vitamini antikanserojen fonksiyonlarını yerine getirememektedir. D vitamini hücre döngüsünü kesintiye uğratarak, antiproliferatif ve prostoglandin metabolizmasını azaltıcı etkisi ile antiinflamatuar etkisini ve apoptoz karşıtı protein ekspresyonunu baskılayarak proapoptoz etki göstermektedir (4).

Siçanlar üzerinde yapılan bir çalışmada D vitamini analoglarının tümör hücre büyümesini inhibe ettiği gösterilmiştir. Fareler üzerinde yapılan bir çalışmada ise; malign tümör hücrelerini azalttığı bildirilmiştir (4). VDR ekspresyonundaki bozulmalar akut miyeloid lösemi (AML) için prognostik faktör olarak kabul edilmektedir. VDR eksikliği hematopoietik ve lösemi kök hücrelerinin sayısında artışa neden olmaktadır. VDR agonistlerinin hipometilasyon ajanlarıyla ilişkisi lösemi kök hücre azalmasını desteklemektedir. Bununla ilişkili olarak, sıçan çalışmalarında VDR agonistlerinin, AML tümör yükünü azalttığ1 gözlemlenmiştir. $\mathrm{Bu}$ nedenle VDR, kök hücre homeostazı ve lösemi yayılımında düzenleyici olarak işlev görmektedir (26).

Bağırsak mukozal ortamının homeostazının ve bağırsak florasının korunması ile tümör oluşumu inhibe edebilmektedir. D vitaminin makrofajlara bağlanabileceğini, antibakteriyel peptitlerin üretimini indükleyebileceği, seçici olarak patojen bakterileri ölüme gönderebileceği ve bağırsak bakterilerinin kolonizasyonu kolaylaştırabileceği bilinmektedir (27). D vitamini reseptörlerinin hipoksi ortamda kolon mukozal bariyer proteinlerinin değişimine olan etkisinin araştırıldığı bir çalışmada, VDR'nin düzenleyici işlev gördüğü ve bu sayede D vitaminin mukoza bariyerini koruyucu etkinlik gösterdiği sonucuna varılmıştır (28). Lactobacillus acidophilus ve Bifidobacterium bifidum probiyotiklerinin, VDR reseptör ekspresyonu ve ilişkili biyokimyasal parametrelerin değiştirilmesi yoluyla farelerde kolon kanserine karşı korunmada önemli bir rol oynayabileceği bildirilmiştir (29). D vitamini düzenlenmesinde esansiyel bir gen olan CYP24A1, immun sistem aktivasyonunda ve tümörogenez inhibisyonunda önemli role sahiptir. Buna ek olarak, CYP24A1 büyük ölçüde kanser riski ile ilişkili bulunmuş, potansiyel kanser teşhisi ve prognozu için bir gösterge olarak önerilmiştir. D vitamini metabolizmasında 25-hidroksivitamin D böbreklerde CYP27B1 tarafindan kodlanan 1a-hidroksilaz enzimi ile aktif form olan $1,25(\mathrm{OH})_{2} \mathrm{D}_{3}$ 'e dönüştürülür ve dolaşıma salınır. Daha sonra dolaşımdaki $1,25(\mathrm{OH})_{2} \mathrm{D}_{3}$, CYP24A1 tarafından kodlanan 24-hidrolaz enzimleri tarafından parçalanır. $\mathrm{Bu}$ nedenle da CYP24A1'in D vitamininin katabolizmasından sorumlu temel enzim olduğunu düşünülmektedir. CYP24A1 rs4809960, rs6022999, rs2585428, rs6068816 gibi polimorfizmler içermektedir. Bu polimorfizmlerden rs4809960, rs6022999 özellikle kolon kanseri olmak üzere kolorektal kanser riski ile anlamlı düzeyde ilişkili olduğu, rektum kanseri ile ilişkili olmadığı gözlenmiştir. Diğer polimorfizmler olan rs2585428, rs6068816 ile kolorektal kanser arasında ilişki gözlemlenmemiştir $(30,31)$.

Kanser hastalarında serum D vitamini düzeylerinde düşüklük görülmektedir. 1940 hastanın incelendiği bir çalışmada \%71 oranında yetersizlik ve eksiklik saptanmıştır. Başka bir çalışmada ise; D vitamini seviyelerinin düşmesi ile birlikte tümör hücre büyüklüğü ve yayılımda artış gözlenmiştir (4). Kolorektal kanser modellemesi yapılmış farelerde yapılan çalışmada; D vitamini eksikliğinin kolorektal kanserli farelerde enterit ve bağırsak bozulmasını arttırdığı gözlemlenirken, D vitamini takviyesinden sonra 


\section{KAYNAKLAR}

hastalığın prognozunda iyileşme olduğu bildirilmiştir. D vitamini, özellikle bağırsak probiyotiklerinin, Akkermansia muciniphila aracılı kolon bariyeri bütünlügünün düzenlenmesi ve bağırsak florasının homeostazı üzerinde önemli bir düzenleyici etkiye sahiptir. D vitamini eksikliği, yüksek kolorektal insidansı ile kuvvetli ilişkili bulunurken; D vitamini takviyesinin kolorektal kanser oluşumu ve gelişimini engelleyebileceği, bağırsak florasını düzenleyebileceği, özellikle A. muciniphila aracılı kolon bariyeri bütünlüğünün düzenlenmesi yoluyla kolorektal kanserin tersine çevrilmesinde rol oynayabileceği sonucuna varılmıştır (27). 25-hidroksivitamin D'nin kolorektal kanser hastalarında prognostik bir değere sahip olduğu düşünülmektedir. Bununla birlikte, 25-hidroksivitamin D konsantrasyonu, onkolojik tedavi yöntemlerinden olan cerrahiden güçlü bir şekilde etkilenmektedir. Operasyon sonrası yüksek 25-hidroksivitamin vitamin D konsantrasyonları daha iyi sağkalım ile ilişkili bulunmuştur (32). Üçüncü evre kolon kanseri tanısı almış 1016 hasta ile gerçekleştirilen çalışmada tanı sonrasında yüksek D vitamini düzeyinin nüksü azaltmak ve sağkalımı iyileştirmek ile ilişkili olduğu gösterilmiştir (33).

\section{SONUÇ}

D vitamini eksikliği dünyada bir halk sağlığı sorunudur. D vitamini pek çok biyolojik süreçte yer alarak hormon benzeri etki göstermektedir. D vitaminin birçok kanser türüne karşı koruyucu ve hastalığın prognozunda olumlu etkileri olduğunu gösteren çalışmalar mevcuttur. İşlev gösterdiği yolaklar ile genomik veya epigenetik olarak kanser progresyon ve prognozuna etki edebilmektedir. D vitamini veya analogları üzerinde yapılan çalışmalardan elde edilen kanıtlar, anti-proliferatif, anti-anjiyogenez, bağışıklık modülasyonu etkileri ile $\mathrm{D}$ vitaminin antitümör etkilere sahip olabileceğini göstermektedir. Kanser hastalarında D vitamini düzeyi yapılan çalışmalarda genellikle düşük düzeylerde bulunmuş ve $\mathrm{D}$ vitamini düzeyi düşüklüğü genellikle kolorektal kanser için risk faktörü olarak kabul edilmiştir. Tedavi boyunca da D vitamini düzeylerinin yüksek olması sağkalımı arttırma ile ilişkili bulunmuştur. Bunun yanı sıra, D vitamininin kolorektal kanser üzerindeki etkilerini gözlemlemek, kolorektal kanserin yavaş ilerleyebilen prognozu, güneş ışığına mağruz kalmanın neden olduğu endişeler gibi faktörler nedeniyle tartışmalıdır. Sonuç olarak, kolorektal kanser ve D vitamini arasındaki ilişkinin aydınlanması için daha fazla çalışmaya ihtiyaç duyulmaktadır.
1. Padmanabhan S, Waly MI, Taranikanti V, Guizani N, Rahman MS, Ali A, Al-Attabi Z, Deth RC. Modifiable and non-modifiable risk factors for colon and rectal cancer. Bioactive Components, Diet and Medical Treatment in Cancer Prevention. 2018; 121-130.

2. GLOBOCAN. İnternational Agency for Research on Cancer, World Health Organization. Erişim Adresi: http://gco.iarc.fr/ today/online-analysis-pie. [Erişim tarihi 06.10.2020]

3. Camara $\mathrm{AB}$, Brandao IA. The role of vitamin $\mathrm{D}$ and sunlight incidence in cancer. Anti-Cancer Agent in Medical Chemistry. 2019; 19(11): 1418-1436.

4. Alptekin İM. Anti-Kanser Etkiler Işı̆̆ında D vitamini ve Kanser. ACU Sağl1k Bil Derg. 2017;2:70-74.

5. O'Neill AM, Burrington CM, Gillaspie EA, Lynch DT, Horsman MJ, Greene MW. High-fat westren diet-induced obesity contributes to increased tumor growth in mouse models of human colon cancer. Nutrition Research. 2016; 36: 1325-1334.

6. Akın H, Tözün N. Diet, Mikrobiota and Colorectal Cancer. J Clin Gastroenterol. 2014; 48(1): 67-69.

7. Zamora-Ros R, Cayssials V, Jenab M, Rothwell J, Fedirko $\mathrm{V}$, Aleksandrova K, et. al. Dietary intake of total polyphenol and polyphenol classes and the risk of colorectal cancer in the European Prospective Investigation into Cancer and Nutrition (EPIC) cohort. European Journal of Epidemiology. 2018; 33(11): 1063-1075.

8. T.C. Sağlık Bakanlığı Halk Sağlığı Genel Müdürlüğü Kanser Dairesi Başkanlığı. 2014 Yılı Türkiye Kanser İstatistikleri. https://hsgm.saglik.gov.tr/tr/kanser-istatistikleri/yillar/2014yili-turkiye-kanser-istatistikleri.html. [Erişim tarihi 06.10.2020]

9. Ratjen I, Schafmayer C, Di Giuseppe R, Waniek S, PlachtaDanielzik S, Koch M et. al. Postdiagnostic Mediterranean and Healthy Nordic Dietary Patterns Are Inversely Associated with All-Cause Mortality in Long-Term Colorectal Cancer Survivors. The Journal of Nutrition. 2017; 147(4): 636-644.

10. Bastide NM, Chenni F, Audebert M, Santarelli R, Tache $\mathrm{S}$, Naud $\mathrm{N}$ et. al. A Central Role for Heme Iron in Colon Carcinogenesis Associated with Red Meat Intake. Cancer Research. 2015; 75(5): 870-879.

11. Song Y, Liu M, Yang F, Cui L, Lu X, Chen C. Dietary Fibre and the Risk of Colorectal Cancer: a Case-Control Study. Asian Pacific Journal of Cancer Prevention. 2015; 16(9): 3747-3752.

12. Qamar TR, Igbal S, Syed F, Nasir M, Rehman H, Iqbal MA et. al. Impact of novel prebiotic galacto-oligosaccharides on various biomarkers of colorectal cancer in wister rats. Int J Mol Sci. 2017; 18: 1785-1797.

13. Rivera-Huerta, M, Lizárraga-Grimes V, Castro-Torres I, Tinoco-Méndez M, Macías-Rosales L, Sánchez-Bartéz F et. al. Functional Effects of Prebiotic Fructans in Colon Cancer and Calcium Metabolism in Animal Models. BioMed Research International. 2017: 1-10.

14. McNabney SM, Henagan TM. Short Chain Fatty Acids in the Colon and Peripheral Tissues:A focus on Butyrate, Colon 
Cancer, Obesity and İnsulin Resistance. Nutrients. 2017; 9(12):1348. doi:10.3390/nu9121348.

15. Uzunlulu M, Telci Caklili Ö, Oğuz A. Association between metabolic syndrome and cancer. Ann Nutr Metab. 2016; 68: 173-179.

16. O'Keefe SJD. Diet, microorganisms and their metabolites, and colon cancer. Nat Rev Gastroenterol Hepatol. 2016; 13(12): 391-706.

17. Ward HA, Norat T, Overvad K, Dahm CC, Bueno-deMesquita HB. Pre-diagnostic meat and fibre intakes in relation to colorectal cancer survival in the European Prospective Investigation into Cancer and Nutrition. British Journal of Nutrition. 2016; 116(2): 316-325.

18. Wang W, Yu S, Huang S, Deng R, Ding Y, Wu Y. A complex role for calcium signaling in colorectal cancer development and progression. Mol Cancer Res. 2019; 17(11): 2145-2153.

19. Bizzaro G, Antico A, Fortunato A, Bizzaro N. Vitamin D and Autoimmune Diseases: İs Vitamin D Receptor(VDR) Polymorphism the Culprit? IMAJ. 2017; 19(7): 438-443.

20. Meeker S, Seamons A, Maggio-Price L, Paik J. Protective links between vitamin $\mathrm{D}$, inflammatory bowel disease and colon cancer. World J Gastroenterol. 2016; 22(3): 933-948.

21. T.C. Sağlık Bakanlığı. Türkiye Beslenme Rehberi - TÜBER 2015. T.C. Sağlık Bakanlığı Yayın No: 1031, Ankara 2016. S. 172, 217.

22. Vurgun E, Evliyaoğlu O, Yıldırmak S. Kanıta dayalı laboratuvar: D vitamini yetersizlik sınırlarının belirlenmesi. Med Bull Haseki. 2016; 54: 76-82.

23. Al-Ghafari AB, Balamash KS, Doghaither AA. Relationship between serum vitamin $\mathrm{D}$ and calcium levels and vitamin D gene polymorphisms in colorectal cancer. BieMed Research İnternational. 2019. Doi: https://doi. org/10.1155/2019/8571541.

24. Feldman D, Krishnan AV, Swami S, Giovannucci E, Feldman BJ. The role of vitamin D in reducing cancer risk and progression. Nature. 2014; 14: 342-357.
25. Lu R, Zhang YG, Xia Y, Sun j. Imbalance of autophagy and apoptosis in intestinal epithelium laching the vitamin D receptor. FASEB J. 2019. doi: 10.1096/fj.201900727R

26. Paubelle E, Zylbersztein F, Maciel TT, Carvalho C, Mupo A, Cheok et al. Vitamin D Receptor Controls Cell Stemness in Acute Myeloid Leukemia in Normal Bone Marrow. Cell Rep. 2020; 30(3): 739-754.e4.

27. Zhou X, Chen C, Zhong Y, Zhao F, Hao Z, Xu Y et al. Effect and mechanism of vitamin $\mathrm{D}$ on the development of colorectal cancer based on intestinal flora disorder. J Gastroenterol Hepatol. 2019; 35(6): 1023-1031.

28. Yang H, Wang Z, Jin M, Zhang HM, Chen XF, et al. Effects of Vitamin D Receptor on Mucosal Barrier Proteins in Colon Cells under Hypoxic Environment. Zhongguo Yi Xue Ke Xue Yuan Xue Bao. 2019; 41(4): 506-511.

29. Ranji P, Agah S, Heydari Z, Rahmati-Yamchi M, Alizadeh AM. Effects of Lactobacillus acidophilus and Bifidobacterium bifidum probiotics on the serum biochemical parameters and the vitamin $\mathrm{D}$ and leptin receptor genes on mice colon cancer. Iranian Journal of Basic Medical Sciences. 2019; 22(6): 631636.

30. Yi C, Huang C, Huan W, Wang C, Dong L, Xu G et al. Association study between CYP24A1 gene polymorphisms and cancer risk. Payhology-Research and Practice. 2020. https://doi.org/10.1016/j.prp.2019.152735

31. Wu X, Hu W, Lu L, Zhao Y, Zhaou Y, Xiao Z et al. Repurposing vitamin D for treatment of human malignancies via targeting tumor microenvironment. Acta Pharmaceutica Sinica B. 2019; 9(2): 203-219.

32. Markotic A, Langer S, Kelava T, Vucic K, Turcic P, Tokic $\mathrm{T}$ et al. Higher Post-Operative Serum Vitamin D Level is Associated with Better Survival Outcome in Colorectal Cancer Patients. Nutr Cancer. 2019; 71(7): 10781085.

33. Fuchs MA, Yuan C, Sato K, Niedzwiecki D, Ye X, Saltz LB et al. Predicted Vitamin D Status and Colon Cancer Recurrence and mortality in CALGB 89803(Alliance). Annals of Oncology. 2017; 28(6): 1359-1367. 